Historic, archived document

Do not assume content reflects current scientific knowledge, policies, or practices. 



\section{Fancy Oregon Asters}

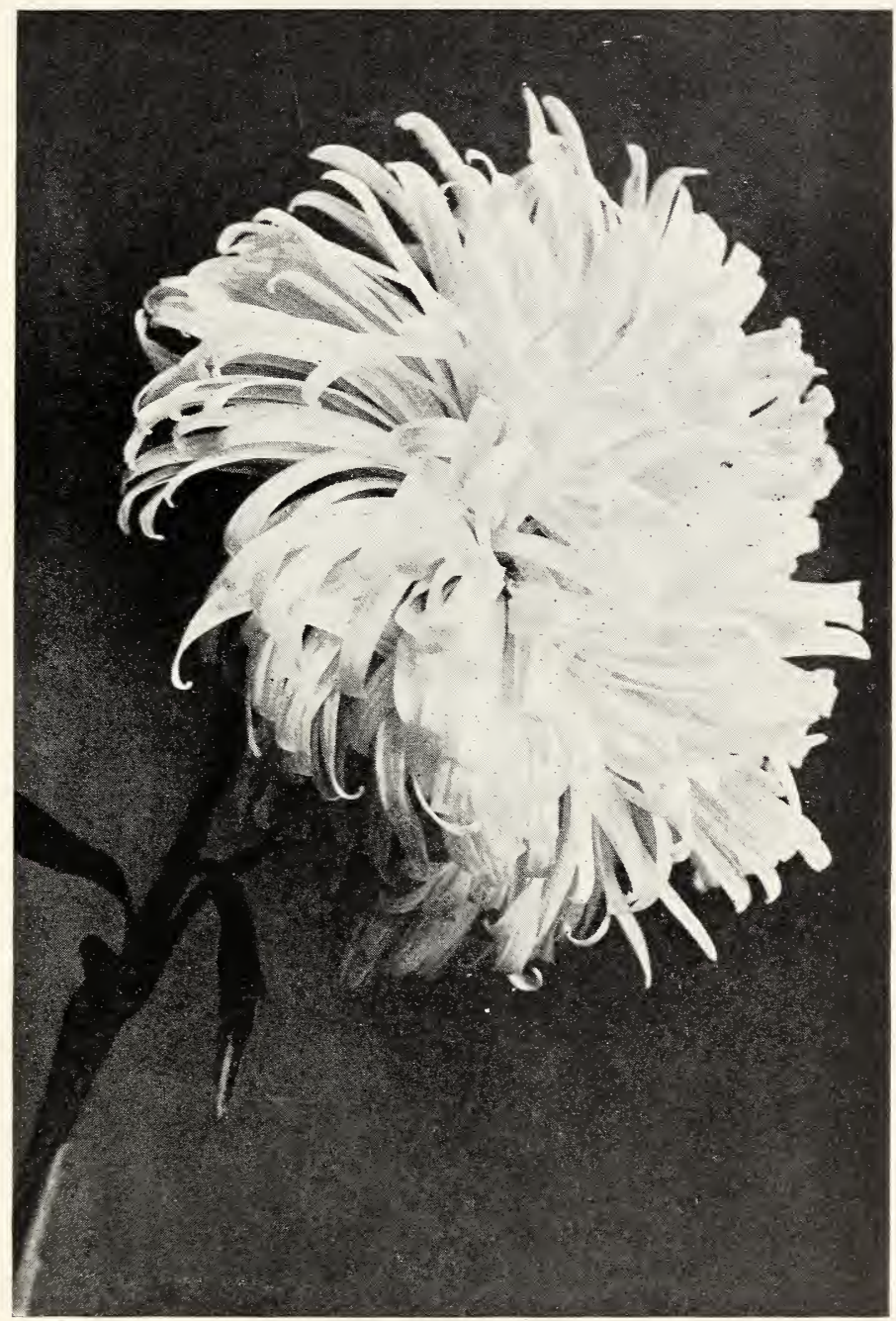

HERBERT \& FLEISHAUER Aster Specialists McMINNVILLE, OREGON 


\section{TERMS OF SALE}

\section{Credit}

Credit is chesrfully extended to those of approved standing or a discount of three percent may be deducted where cash accompanies orders amounting to $\$ 5.00$ or over.

Florists are honest but in order to guard against the pilfer who sticks up his card, we insist that cash accompany orders from unknown correspondents.

\section{Our Responsibility}

All errors, such as omissions, duplications and miss-addressing of packages will be promptly corrected as far as possible $\mathrm{cr}$ the money paid for the seed will be refunded.

\section{Parcel Post}

Most of the Aster Seed is sent by mail and safe delivery is guaranteed if extra money is sent to cover Postal Insurance as follows: Orders amounting to $\$ 5.00$ or less three cents; $\$ 5.00$ to $\$ 25.00$ five cents; $\$ 25.00$ to $\$ 50.00$ ten cents; $\$ 50.00$ to $\$ 100.00$ twenty-five cents.

\section{Our Guarantee}

We grow all the seed offered in this catalogue and take every precaution to deliver fresh stock, true to name. We can not however give any warranty as to results and will not be responsible beyond that of replacing the seed or refunding the price paid at the time of purchase, but we do rely upon the intelligence of the growers in realizing that no human power can control the life of a seed or the results therefrom, which depend on conditions of climate, soil and cultivation. 


\section{TO THE FLORIST TRADE:}

In presenting our new catalogue our purpose is simply to illustrate and give plain descriptions of the Asters of which we have seed to offer. Since these descriptions are given as the Asters grow in Oregon it is to be expected that they may vary in different localities. a fair wage.

Our seed is all hand picked by white labor who are paid

Having selected Aster Seed growing as our life work, we shall keep improving varieties as long as we live. During our twenty years of careful attention to Asters many new ones of merit have developed, some of which may be placed on the market in the near future.

It is true that we are not seeking a reputation for cheapness but rather place quality first, remembering that quality is the real test of value. Products offered at a low price are not always the cheapest. This is especially true in plant life where quality often means success or failure.

The fact that so many of our customers have been constant patrons for years indicate that boih quality and service have been satisfactory. Many orders are received on account of recommendations by our customers to their friends and we consider the users of these seeds our best advertisers. Thanks for your generous patronage in the past. Remember it is our purpose to serve you right each year.

We feel that our prices are as low as the best grade of Aster Seed can be sold and that no one can supply stock equal to ours for less money. 


\section{larbert \& Fleishauer}

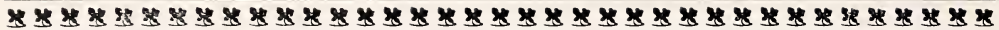

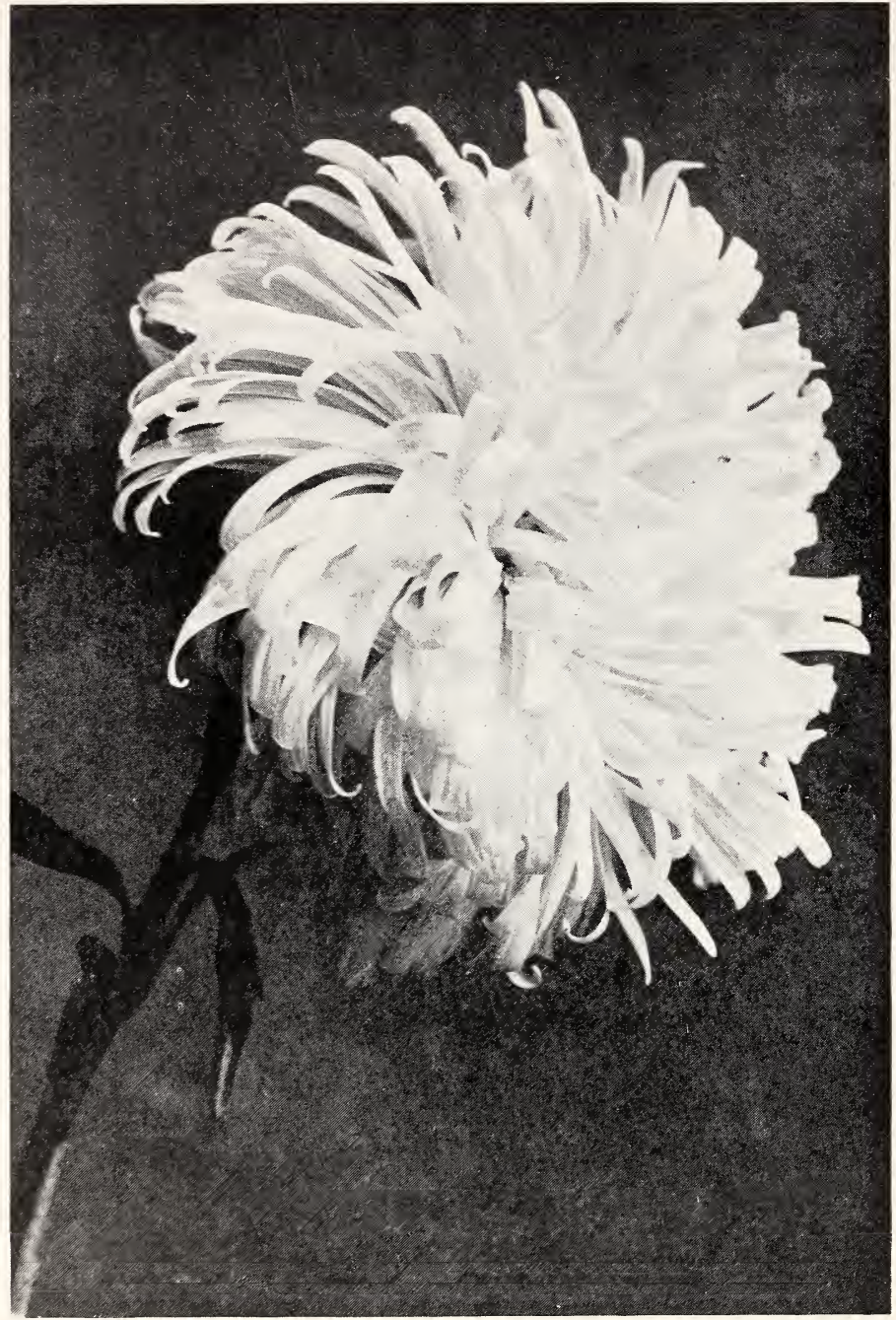

\section{Pacific Beauty}

A beautiful light blue of the comet class, the best of this shade to date. With gcod cultivation and disbudding produces long stemmed, very full petaled flowers 5 to 6 inches in diameter. Ideal for basket and spray work. Midseason to late. Ounce $\$ 3.00,1 / 2$ oz. $\$ 1.55,1 / 4$ oz. $80 \mathrm{c}, 1 / 8$ oz. 45 c, trade packet 25 c. 


\section{NEW ATSTERS ORIGINATING WITH US}

LIGHT BLUE ASTERMUM-A feathery bloom of the Comet Type. Midseason, for prices see page 7 .

MATCHLESS LATE BRANCHING-By far the best of the late branching Asters as the result of years of very pains-taking cultivation and selection. Full description on Page 10. Colors Lavender Pink, Light Blue, Rose Pink and Purple.

\section{हत्या)}

\section{REGARDING ILLUSTRATIONS}

The photographs are made by our local photographer. No retouching is cone, as any one will at once observe by close investigation. The flowers seen in these cuts average from 4 to 6 inches in diameter and a careful study of their perfect form and unusual quality will prove to you why the H. \& F. Quality Asters are so popular.

\section{SPECIAL OFFER}

For the benefit of Florists who want only a small quantity for trial purposes, we offer $25 \mathrm{c}$ trade packets of any five varieties for $\$ 1.00$, ten varieties $\$ 1.75$, fifteen varieties $\$ 2.50$.

\section{EARLY ORDERS}

Each year there occurs some shortage among the many Asters grown for seed and only those ordering early get any of the stock. It will also contribute greatly toward the filling of orders if you order early, as you know it is almost impossible to fill orders promptly during the rush season.

$A$ STER WILT is usually caused by excessive moisture for too A long a time. This infection may take place in the seed bed and not be noticed until the plants are well developed in the field where they may suddenly wilt and die. 


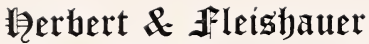

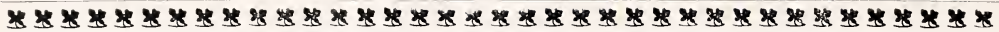

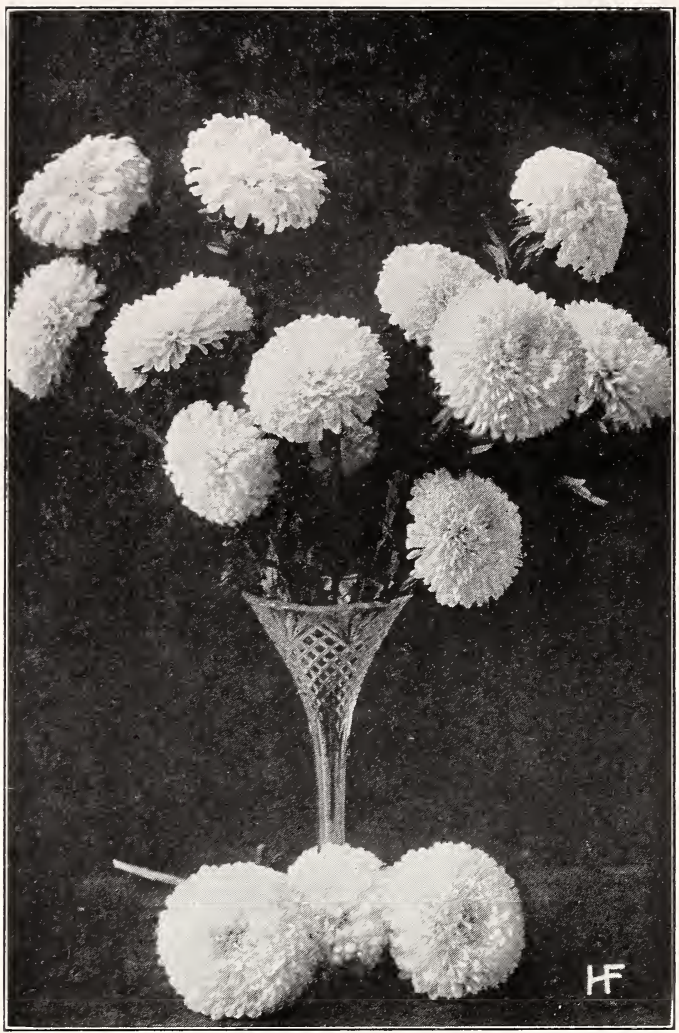

\section{Imperial Asters}

$L A V E N D E R$-A delicate shade of pale lavender.

$D A Y B R E A K$ - An exquisite shade of shell pink. Ounce $\$ 2.50,1 / 2$ oz. $\$ 1.30,1 / 4$ oz. 70 c, $1 / 8$ oz. 40 c, trade packet 25 c.

SOIL heavily enriched the previous year by the liberal use of sta1 ble manure is best for both early and late asters. An application of lime just before planting in field is also beneficial to some soils. 


\section{EARLY ASTERS}

COMMERCIAL PURITY-A commercial strain of this well-known aster which is not as double as our Improved Purity but is equal to any strain sold in the open market. Ounce $\$ 1.50,1 / 2$ oz. $80 \mathrm{c}, 1 / 4$ oz. 45 c, trade packet 25 c.

IMPROVED PURITY --A pure white aster of great beauty distinctive in form. The plant is of most symmetrical habit, usually attaining a height of about 18 to 20 inches and completely loaded with globe shaped double flowers, averaging 2 or 3 inches in diameter and very full to the center. Excellent for bedding and for pot plants, and much used by florists for designs. Extra fine but a very shy seeder. Ounce $\$ 3.00,1 / 2$ oz. $\$ 1.55,1 / 4$ oz. 80 c, $1 / 8$ oz. 45 c, trade packet 25 c.

QUEEN OF THE MARKET-The leading early Aster, of good strong growth and bearing large flowers on long strong stems; begins blooming in July. Used quite extensively for growing under glass. Colors, white, light pink, purple and lavender. Ounce $\$ 1.00,1 / 2$ oz. 50 c, $1 / 4$ oz. 30 c, trade packet 25 c.

THE ROY AL-Among the best asters of recent introduction and is without doubt one of the best general purpose early asters. The stems start from the plant close to the ground. It is vigorous and very productive, yiclding numerous large handsomely proportioned flowers on grod long stems. Sown early inside and planted out with Queen of the Market, will follow that variety closely. Ounce $\$ 2.50,1 / 2 \mathrm{oz}$. $\$ 1.25,1 / 4$ oz. 70 c, $1 / 8$ oz. 40 c.

LAVENDER GEM - Is always full double and the most beautiful shade of lavender yet to be found among early Asters of the Comet type. Flowers are borne on strong stems of good length. Ounce $\$ 2.50,1 / 2$ oz. $\$ 1.25,1 / 4$ oz. 70 c, $1 / 8$ oz. 40 c.

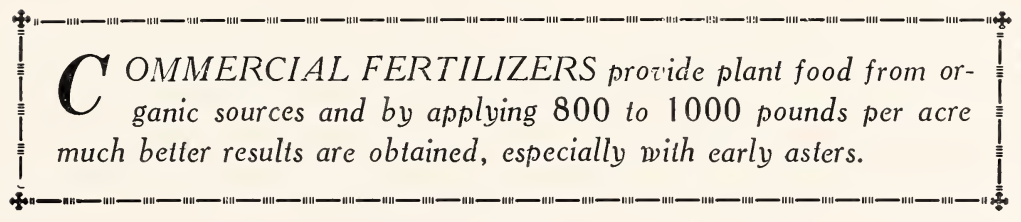




\section{łerbert \& Fleishauter}

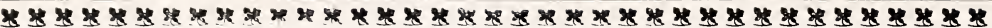

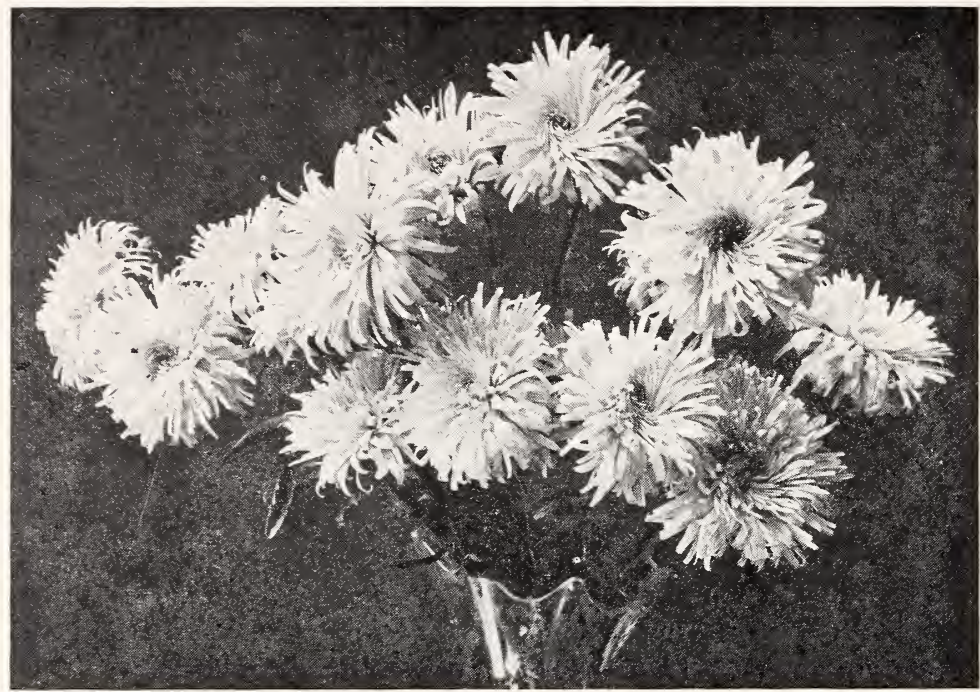

\section{Improved Rochester}

In size and beauty the Rochester is second to none. The petals are $\mathrm{n} \approx \mathrm{rr}=\mathrm{w}$, very long, and gracefully reflexed. The outer petals show completely, while gradually toward the center they bend and curl across each other in magnificent disorder. The robust growth of this aster makes possible its long vigorous stems, giving the plant an exceedingly graceful appearance with its immense feathery flowers. It is one of our best sellers. Colcrs, white, shell pink, lavender, purple, and a most exquisite shade of lavender pink. Ounce $\$ 3.00,1 / 2$ oz. $\$ 1.50,1 / 4$ oz. $80 \mathrm{c}, 1 / 8$ oz. $45 \mathrm{c}$.

GIANT CRIMSON_-A dark velvety crimson which attracts much attention. Is fine for bedding, especially in borders. Height 18 to 24 inches. In Oregon it lasts in bloom from 6 weeks to 2 months. Ounce $\$ 1.50,1 / 2$ oz. 80 c, $1 / 4$ oz. 45 c, trade packet 25 c.

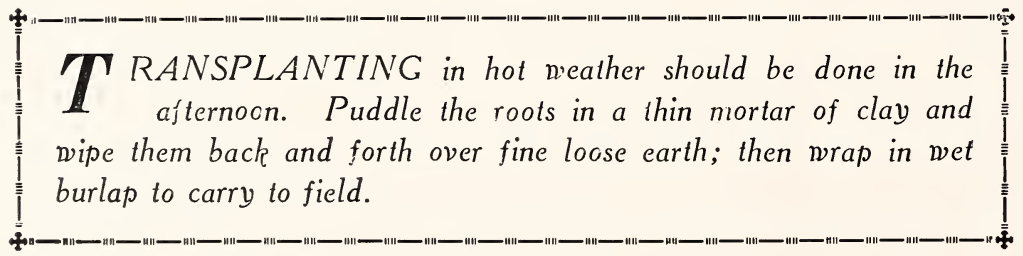




\section{LEADING MID-SEASON COMET ASTERS}

WHITE FLEECE_-An old established aster bearing perfect flowers of a glistening white. Ounce $\$ 2.00,1 / 2$ oz. $\$ 1.05,1 / 4$ oz. $55 \mathrm{c}, 1 / 8$ oz. 30 c.

ASTERMUM - This strain of Giant Comet asters closeiy resembles Crego's Giant but comes into bloom two or three weeks earlier. The plants are upright in growth. The flowers are composed of a multitude of fine long petals giving it a beautiful appearance. Colors, white, pink, light blue and purple. Ounce $\$ 3.00,1 / 2$ oz. $\$ 1.55,1 / 4$ oz. 80 c, $1 / 8$ oz. 45 c, trade packet 25 c.

TRIUMPH COMET-A splendid mid-season Aster with long stems and large full double flowers. A great improvement over the upright Comet Asters offered heretofore. Colors, white and shell pink. Cunce $\$ 2.50,1 / 2$ oz. $\$ 1.30,1 / 4$ oz. 75 c, $1 / 8$ oz. 40 c.

GERMAN COMET - This aster of German origin produces large comet flowers borne on long stems. The plants are of branching habit of crowth and very vigorous. The petals long and so curved as to give the flower a very attractive form. The colors we have to offer this year are white, rosy lilac and azure blue. Ounce $\$ 2.00,1 / 2 \mathrm{oz}$. $\$ 1.05,1 / 4$ oz. $55 \mathrm{c}, 1 / 8$ oz. $30 \mathrm{c}$.

BLACK BEETLE and striped bugs are prevented from doing damage by dusting with Hammond's Slug Shot on a still day, as soon as the plants are grown and again just when the blooms begin to open.

7 ARNISH BUG is held in check by overhead watering. A spray of whale oil soap or herosene emulsion also proves very effectual. The thrifty condition of the plants produced by conserving the moisture in extensive fields, proves bencfic:al as this bug dislikes shade. 



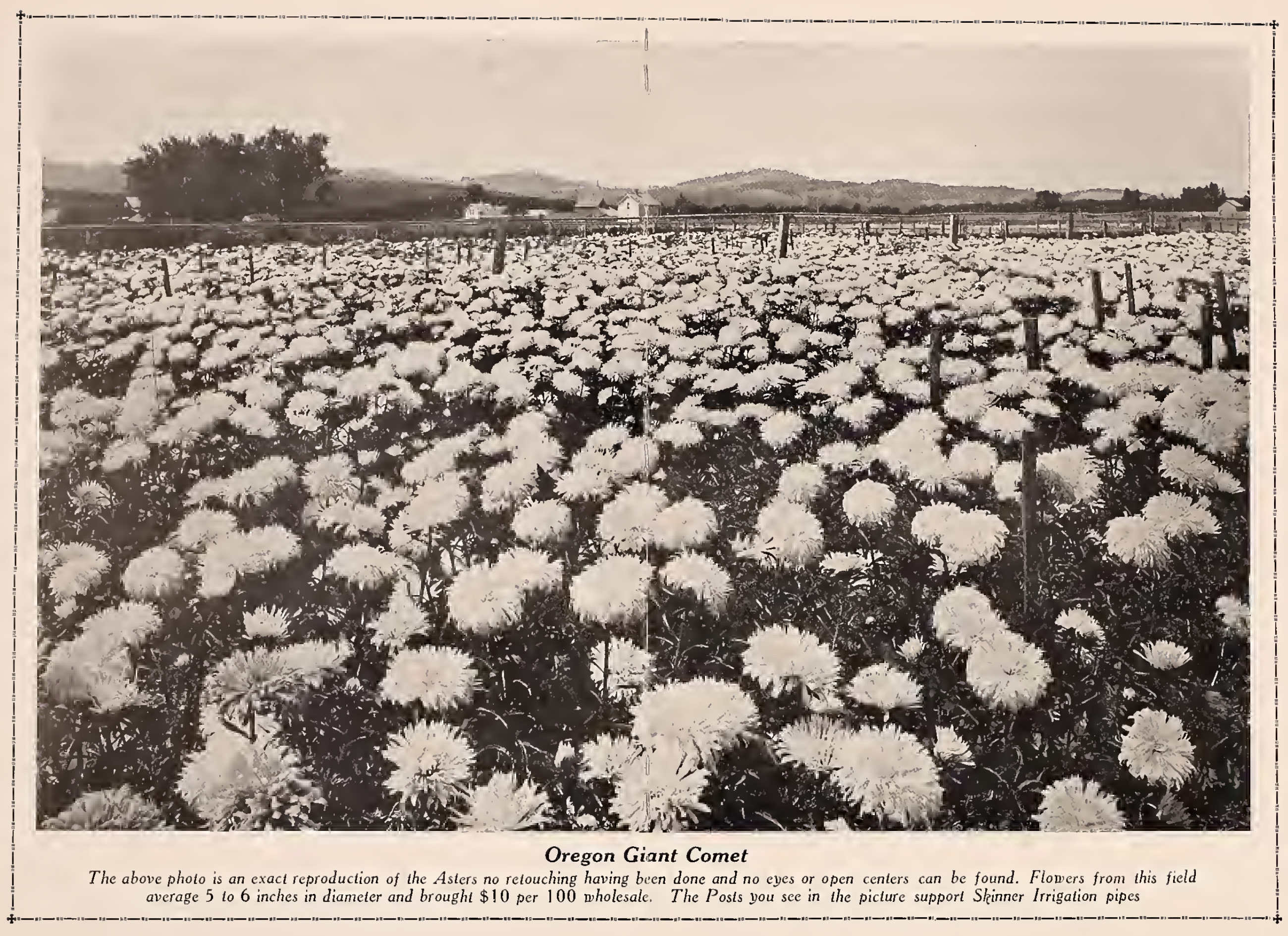




\section{Werbert \& Fleishauer}

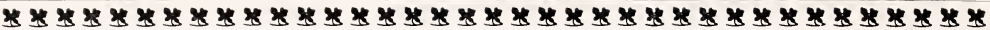

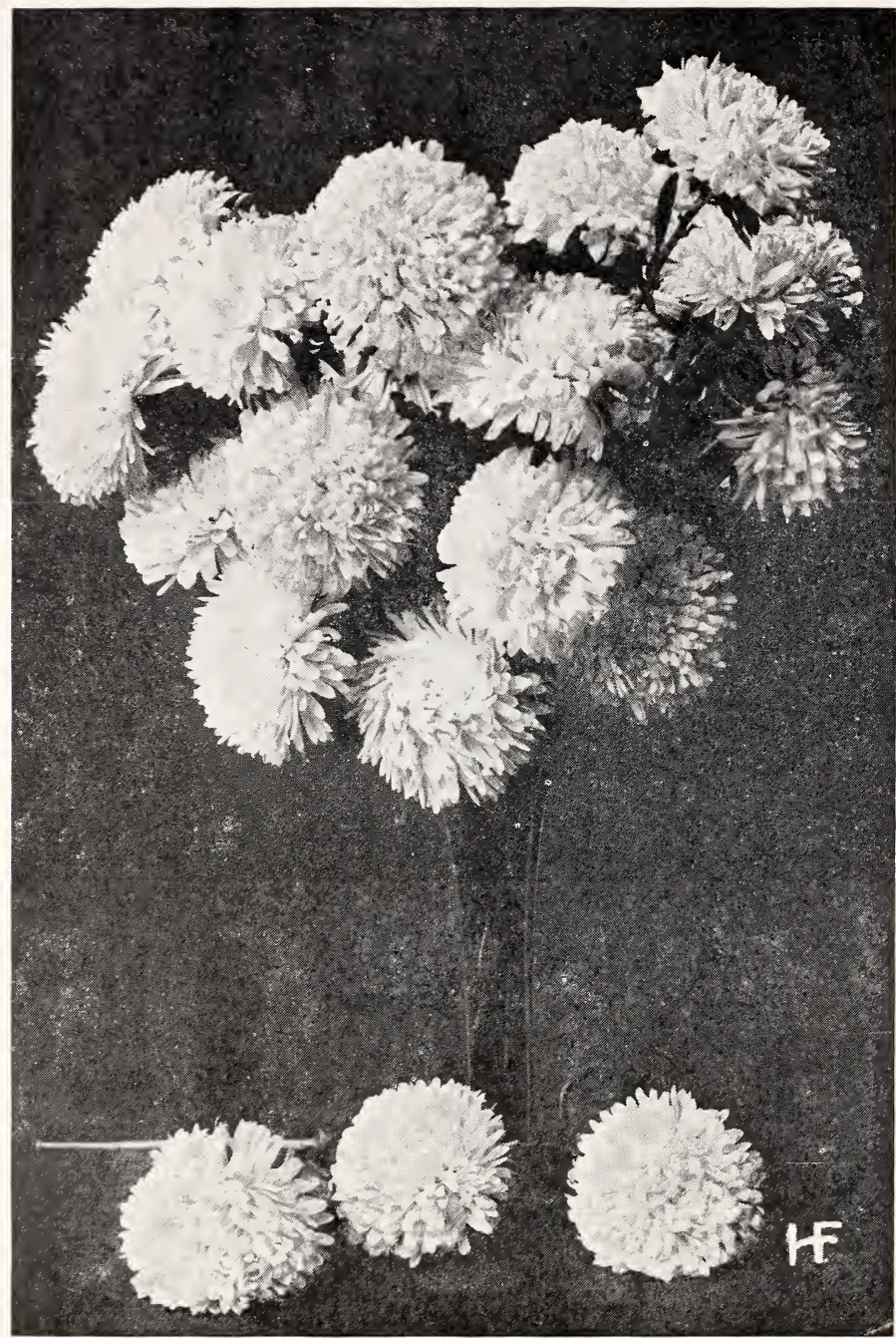

\section{Matchless Late Branching}

This excellent strain of late branching aster of American origin, has steadily improved under rigid culture so that it now fully meets the demand for this type of high class, quick selling commercial aster. The white and shell pink are selections from that remarkable strain of Smith's Peerless. 


\section{Fancy Dregon Alsters}

Light blue, purple, rose pink, and lavender pink, have originated with us. The plants are of strong, sturdy habit of growth bearing their handsome chrysanthemum-like flowers on stiff stems measuring two or three feet in length. The blossoms average about five inches in diameter and the pretty curving of the petals make it a most artistic and finely finished flower. Colcrs, white, shell pink, rose pink, lavender pink, light blue and purple. Ounce $\$ 3.00,1 / 2$ oz. $\$ 1.55,1 / 4$ oz. 80 c, $1 / 8$ oz. 45 c.

BEAUTY ASTERS_A valuable introduction of recent development on account of its coming into bloom later than Superb Late Branching and furnishing good cut flowers from the middle of September until killing frost. The large double flowers are borne on long stiff stems and are similar in form to the Superb Late Branching. We offer five colors: Pink Beauty, American Beauty, rich cherry-rose, similar in color to American Beauty Rose; Lavender Beauty, exquisite soft lavender; Purple Beauty, rich, lustrous, deep purple; September Beauiy, delicate shell pink. Ounce $\$ 2.50,1 / 2$ oz. $\$ 1.30,1 / 4$ oz. 70 c, $1 / 8$ oz. 40 c.

"PEERLESS PINK" ASTER-Has strong, sturdy habit of growth; bears freely almost globular flowers, rarely under 4 inches across and frequently over 5 inches. The color is rich shell-pink, similar in shade but more decided than the late branching. The center petals are prettily incurved, while the wide outer petals reflex, making a most artistic and finely finished flower, and stands cut longer than any other. Ounce $\$ 2.50,1 / 2$ oz. $\$ 1.30,1 / 4$ oz. 70 c, $1 / 8$ oz. 40 c.

HEART OF FRANCE-An admirable Aster which opens red at the beginning, the color deepening with age and retaining its beauty to the end. The petals are apparently changeable from a rich glow to a soft velvety texture. This Aster is surprisingly beautiful in any light, compelling universal admiration and retains its brilliancy for a long time. The flowers are large and full to the center. The plants of a branching type and very sturdy. Ounce $\$ 2.50,1 / 2$ oz. $\$ 1.30,1 / 4$ oz. 70 c, $1 / 8$ oz. 40 c.

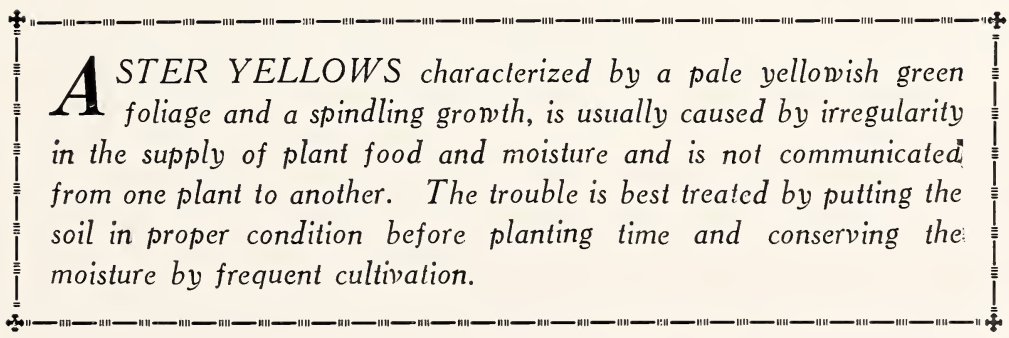




\section{lerbert \& Fleishauer}

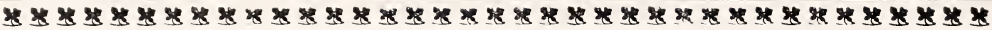

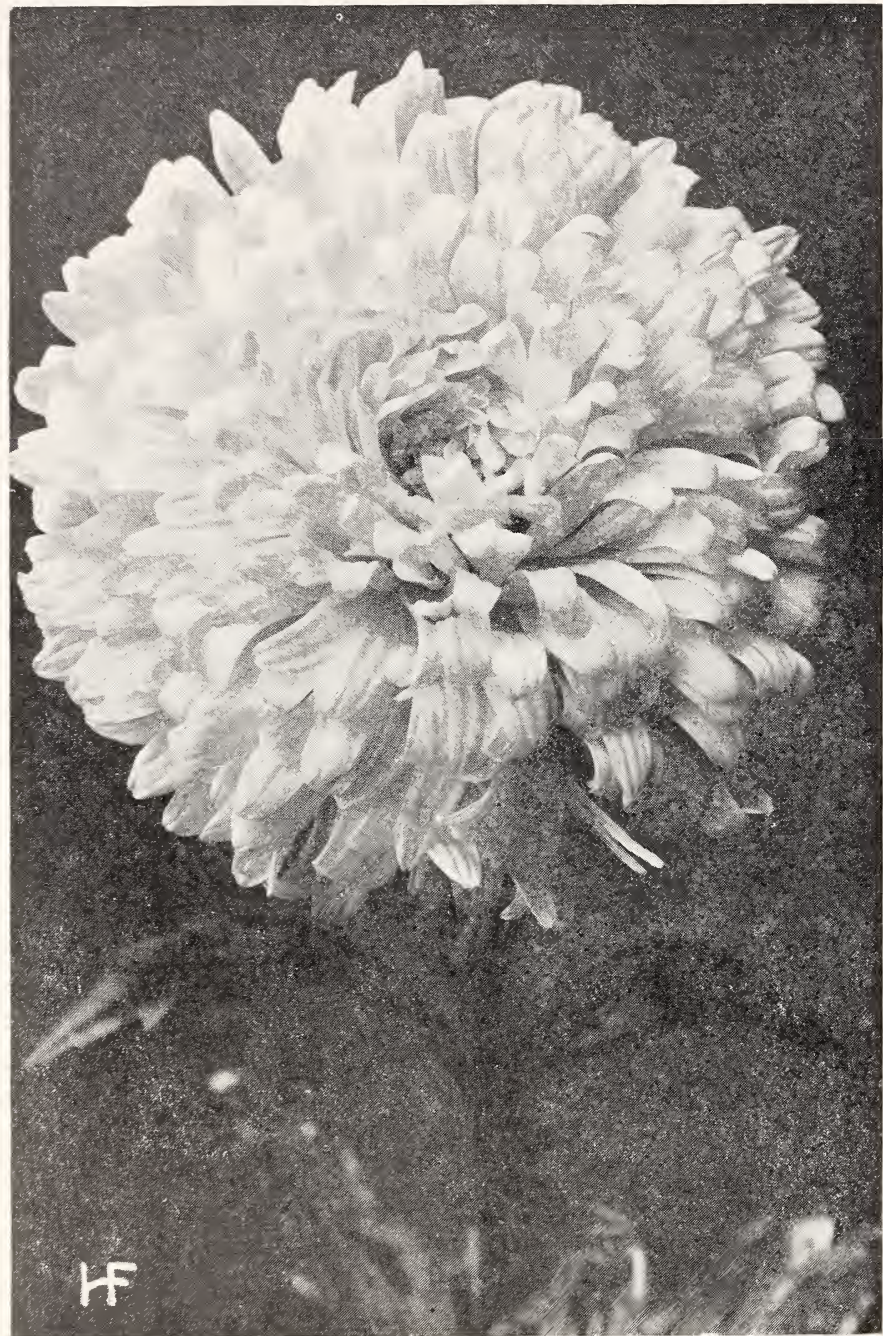

\section{Superb Late Branching}

A careful selection of this well known stock which we have grown successfully for a number of years. The plants are of vigorous growth, two to two and one-half feet high, bearing large, beautiful lasting flowers averaging four to five inches in diameter. Its form along with the length 
Fancy Bregon Alsters

of stem, makes this aster very valuable for cutting. Comes into bloom late and lasts until frost, yielding a profusion of flowers of extraordinary quality. Colors white, shell pink, rose pink, lavender, azure biue, and purple. Ounce $\$ 1.00,1 / 2$ oz. $50 \mathrm{c}, 1 / 4$ oz. $30 \mathrm{c}$.

INVINCIBLE ASTERS-Invincible Asters are a superior race in many ways. The plants are of healthy growth, robust and of a branching habit and if properly grown attain a height of 2 to 3 feet, producing massive blooms on long stems. The flowers are of perfect form and exceedingly double to the center. When well grown the Invincible Asters average $3 \frac{1}{2}$ to 4 inches in diameter.

Crimson Brilliant, rich, bright red.

Deep Pink, lively rose pink.

Lavender, a rich silvery shade.

Pearl Pink, a delicate blush and shell pink.

$V$ iolet Purple, rich velvety purple.

Pure White, finest snow white.

Ounce $\$ 2.00,1 / 2$ oz. $\$ 1.05,1 / 4$ oz. 55 c, $1 / 8$ oz. 30c.

PRIMROSE QUEEN-Primrose Queen is a striking yellow asier of Victoria shape, a unique variety and without question the best yellow aster to date. The flowers are very full and ball shaped, with centers covered. The plants are of the branching type and very vigorous and a shy seeder. Ounce $\$ 3.00,1 / 2$ oz. $\$ 1.55,1 / 4$ oz. $80 \mathrm{c}$, $1 / 8$ oz. 45 c.

BALL'S WHITE ASTER-A splendid Giant Aster of the late branching type, growing to a medium height with full-centered blossoms; ideally formed for long distance shipping. Ounce $\$ 3.00,1 / 2 \mathrm{oz}$. $\$ 1.55,1 / 4$ oz. 80 c, $1 / 8$ oz. 45 c.

NEW RED ASTER "SENSATION"-This is the reddest of all Red Asters, the color being a rich garnet or ox blood red which glistens in the sunshine like a live coal. The plants are of free-branching habit about 18 inches high; the very double flowers averaging $31 / 2$ inches across, are borne freely on stems a foot long. In bloom from early in August till the close of September. The intense color shows up well when cut and makes a very brilliant bit of color in a bed or border. Ounce $\$ 2.50,1 / 2$ oz. $\$ 1.30,1 / 4$ oz. 70 c, $1 / 8$ oz. 40 c.

GETTING PLANTS in the field requires no great shill but growth will start quicker and plants will be stronger if the soil is not too wet and the roots are not folded together in setting. 


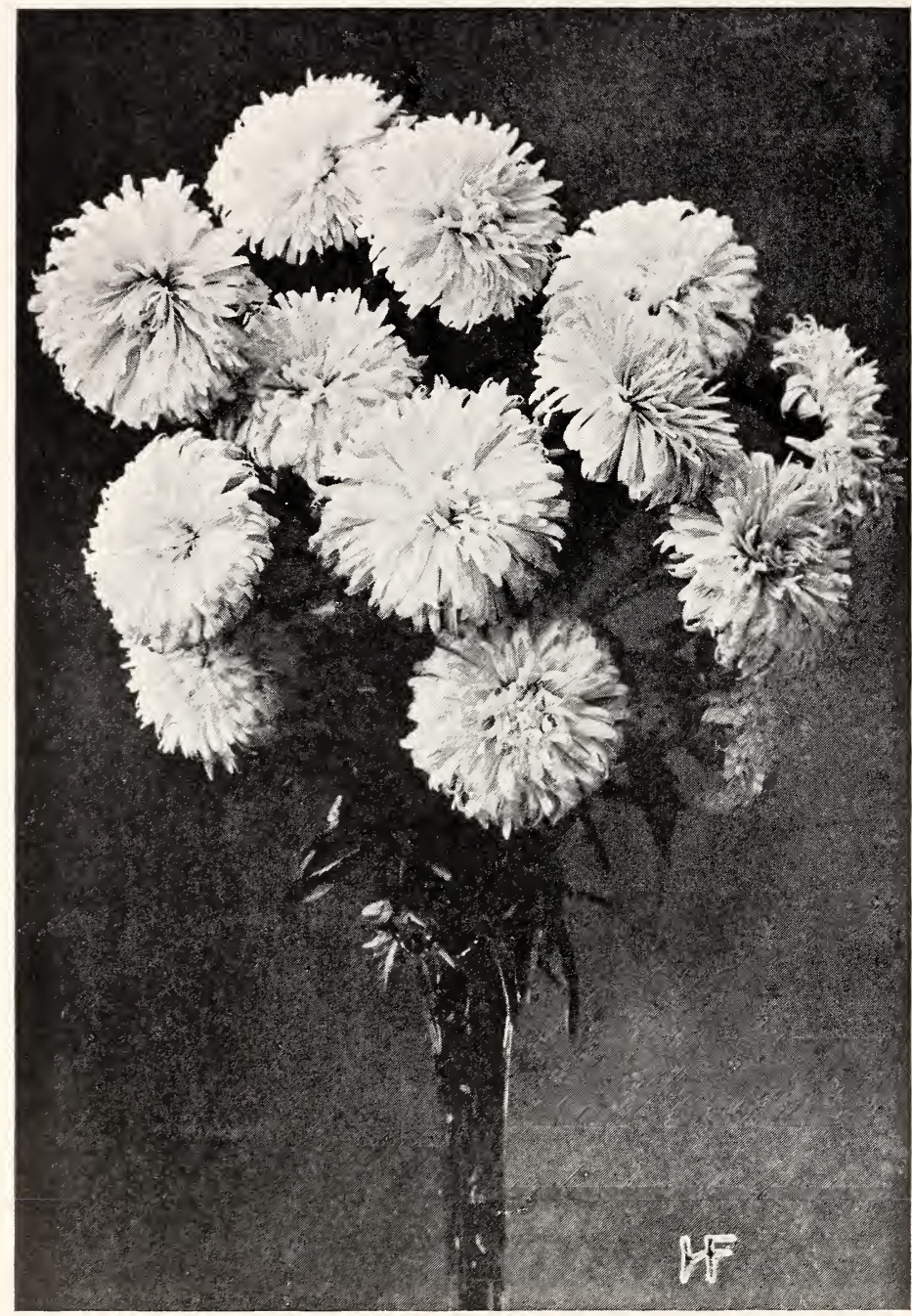

\section{Oregon Giant Comet}

The Oregon Giant is undoubtedly the finest of the Comet strain of asters yet produced, judging from the commercial grower's point of view. The immense fluffy flowers are most beautifully formed, averaging five to six inches in diameter and very full to the center. The form of the flower 
Fancy Bregon Alsters

together with the length of stem, places it at the head of asters for cutting. The plants are free blooming and vigorous, producing strong stems twenty to thirty inches long. The flowers when cut, keep longer in good condition than many Asters of this type. In bloom from mid-August through Septe ber. Colors, white, shell pink, rose pink, light blue and purple. Ounce $\$ 3.00,1 / 2$ cz. $\$ 1.55,1 / 4$ oz. $80 \mathrm{c}, 1 / 8$ oz. 45 c.

CALIFORNIA GIANT-The California Giant is without doubt the latest flowering aster in their class; coming into bloom about the middle of September and furnishing magnificent blooms until killed by frost. The plants are unusually vigorous reaching a height of $21 / 2$ to 3 feet. The shaggy blossoms measure 5 inches and over. The petals are wide and thick insuring better keeping qualities in transit and less damage from rain. The Giants are sure to become a peer among asters. After two years of careful selection since obtaining stock of this, we are offering:
Giant Peach Blossom
Giant Rose Pink
Giant Light Blue
Giant Purple
Paeony Light Blue
Paeony Peach Blossom

Ounce $\$ 5.00,1 / 2$ oz. $\$ 2.50,1 / 4$ oz. $\$ 1.30,1 / 8$ oz. 70 c, trade packet $50 \mathrm{c}$.

\section{E(t)in}

\section{LIBERAL SEED SOWING FOR CROP INSURANCE}

Never risk your entire crop on one planting. By experience you will socn learn which varieties grow best in your soil and the types and colors most in demand by your trade. By making frequent sowings of these you are sure to have good plants ready when the soil is in proper condition for setting plants in field. The cost of extra seed for this is smail as compared with the value of your crop. Always try to raise more plants than you need, by so doing you will add much to the certainty of your crop and at the same time aid greatly toward the insurance and prosperity of a rapidly growing and increasingly profitablc industry.

\section{QUALITY AND PRICE}

The more closely asters are selected and developed into a full center, the more sparingly they produce seed and the weaker the vitality the second year. After giving careful attention to quality in asters from the first we attribute our increase in business to the quality of the seeds which are offered at fair prices believing that no better aster seed can be obtained. 


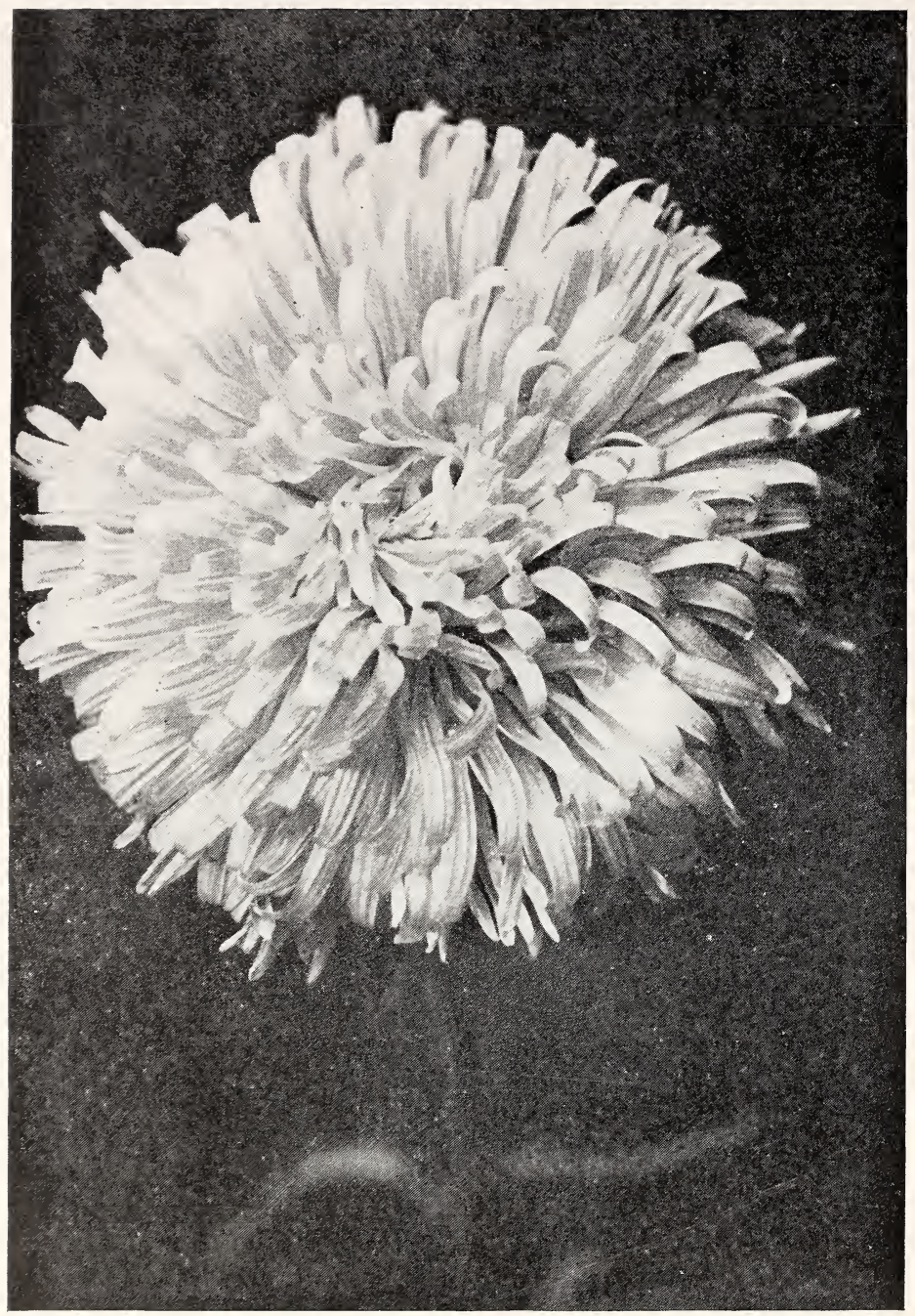

\section{Oregon Giant White Comet Notice the center}

\section{$\ldots$ \\ FANCY OREGON ASTERS}

H. \& F. Seeds you will find are distinctive in quality; and while many growers may doubt that there is a difference in the character of seeds, professional gardeners and expert growers recognize at once the unusual type of aster produced from our seed. 


\section{Make Aster Growing}

\section{A Business}

First Because the Aster in its various forms is quite as indispensable in summer for cutting as are chrysanthemums in early autumn and winter. In our improved types of the aster there is certainly a striking resemblance to its splendor and for many reasons they could justly be entitled "The Chrysanthemums of Summer." For these improved forms surely defy in fantastic appearance as well as in size, many varieties of the "Queen of the Autumn."

Second-There is So Much Difference between Aster growing as a business and gambling in Asters that one will mean success while the other spells certain failure. Estimate your market and plan a reasonable acreage annually, increasing your crop in proportion to the demand and success is certain. Whereas if you play the gambler and plant this year because there was a scarcity last year and the business man made some money and then go out of the game next year because Asters were plentiful and the price low, the chances are against you. Aster growing as a business these days almost surely pays.

Third-Wide Awake Florists Everywhere are looking for a place to buy a standard quality of asters each year. Don't forget however, that there is no economy in hunting for low priced seed. Ground space is too valuable to plant inferior seed which never yields satisfactory returns for labor expended.

Fourth-The China Aster has responded to the painstaking efforts toward its improvement until, as the season changes into the heat of summer, their beautiful blossoms are smiles of God's goodness. 


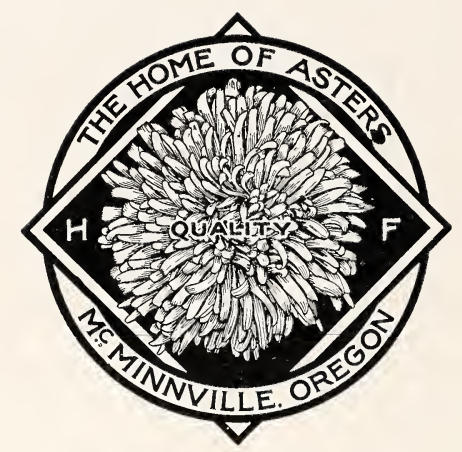

FOUNDED 1904 